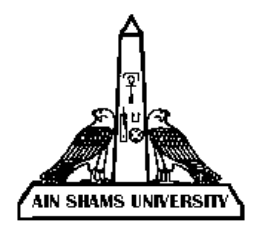

Ain Shams University

Faculty of Education

Curriculum and Instruction Department

\title{
Impact of Problem-Based Learning on Enhancing Critical Thinking Skills of Secondary School EFL Students
}

\author{
A Research Paper \\ Prepared By \\ Kamelia El Sayed Soliman El Safory
}

Supervisors

$\begin{array}{ll}\text { Dr. Magdy Mahdy Aly } & \text { Dr. Dalia Ibrahim Yahya } \\ \text { Professor of Curriculum and } & \text { Lecturer of Curriculum and } \\ \text { Instruction (TEFL) -Faculty of } & \text { Instruction(TEFL) -Faculty of } \\ \text { Education -Ain Shams University } & \text { Education -Ain Shams University }\end{array}$ 
عنوان الرسالة: أثر التعلم القائم على المشكلة في تتمية مهارات التفكير الناقد لاى طلاب المرحلة الثانوية في اللغة الإنجليزية كلغة أجنبية التعان

إسم الطالبة : كامليا السيد سليمان الصافورى

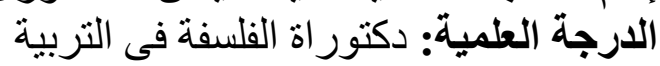
القسم: مناهج و طرق تدريس اللغة الانجليزية كلئة كلغة أجنبية المصدر: كلية النربية جامعة عين شمس للانسير

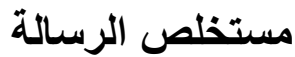

هدفت الدراسة الحالية إلى إستخدام إستراتيجية التعلم القائم على المشكلة في تحسين مهارات

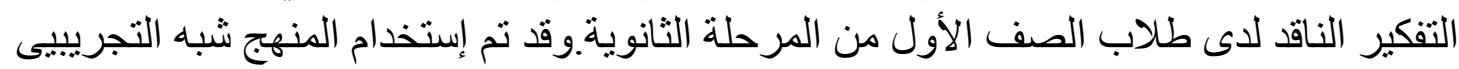

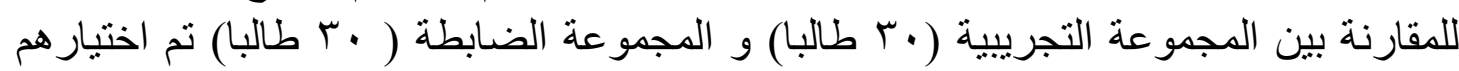

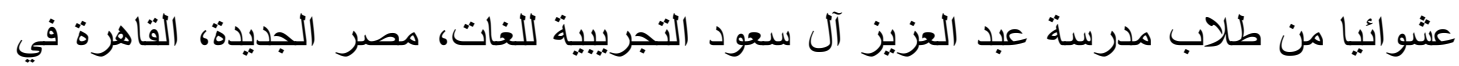

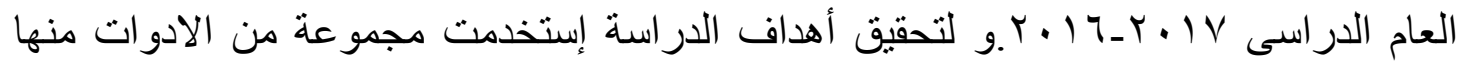

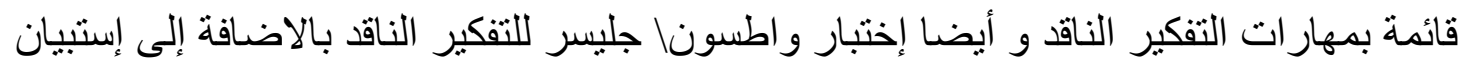

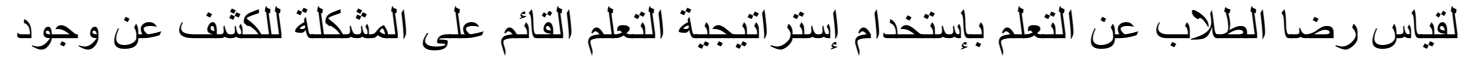

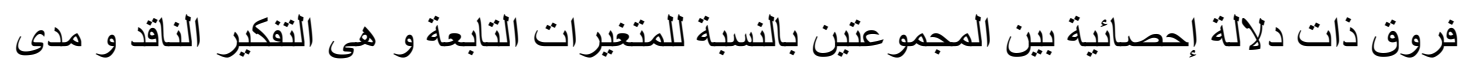

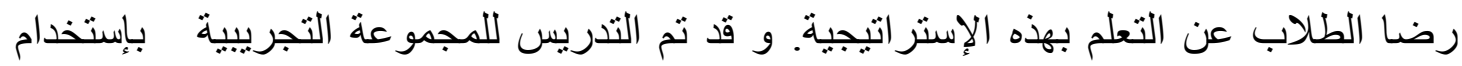

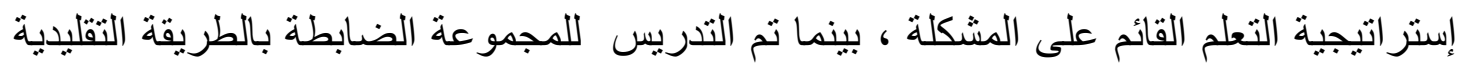

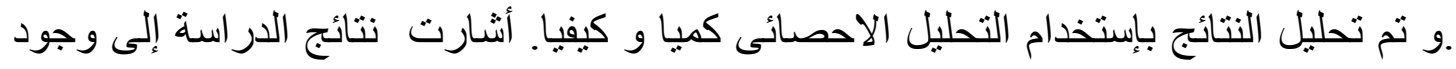
فروق ذات دلالة إحصائية بين المجموعتين التجرييية و الضابطة في اختبار التفكير الناقد ككل

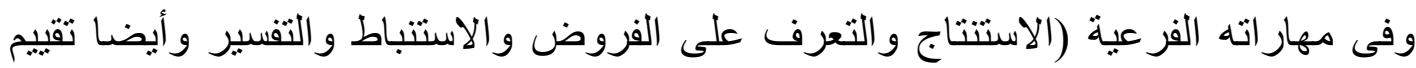

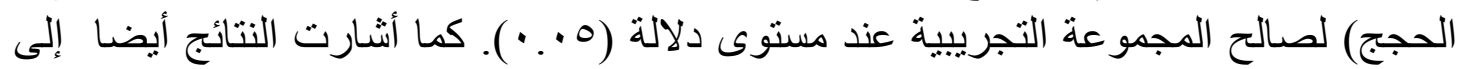
وجود فروق ذات دلالة إحصائية بين منوسط درجات المجموعة التباتية التجريبية في اختبار التفكير

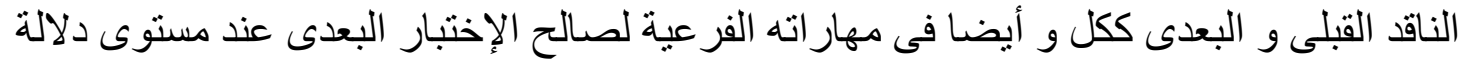

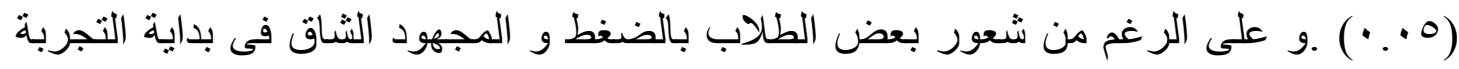

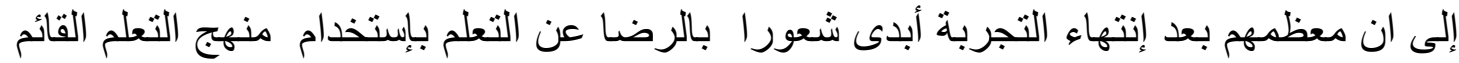

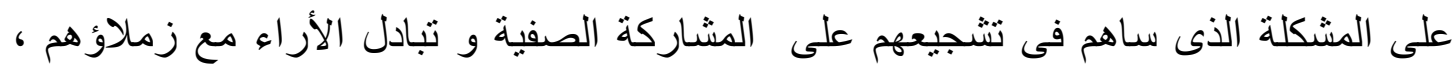

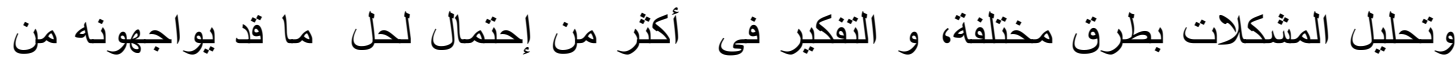

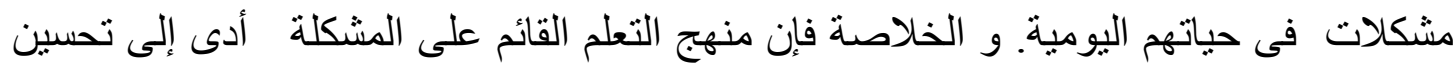
قدرة طلاب المرحلة الثانوية على التفكير الناقد.

الكلمات المفتاحية: التعلم القائم على المشكلة، التفكير الناقد، طلاب المرحلة الثانوية

Research Title: "Impact of Problem-Based Learning on Enhancing Critical Thinking Skills of Secondary School EFL Students"

Researcher's Name: Kamelia El Sayed Soliman El Safory 
Source: Ain Shams University Faculty of Education Curriculum and Instruction Department

\begin{abstract}
The objectives of this study were to investigate the effectiveness of problem-based learning (PBL) in developing critical thinking skills for $1^{\text {st }}$ grade secondary school students. A quasi-experimental pre- post-test experimental /control group design was conducted. Participants were 60 $1^{\text {st }}$ grade secondary students randomly selected from Abd Al Aziz Al Saud experimental language school, Heliopolis, Cairo in 20162017. Students of the experimental group received training through the problem-based learning program, while the control group received regular instruction. Tools of the study included: critical thinking skills checklist, a pre-post Watson -Glaser critical thinking appraisal -short form (WGCTA-S) . The participants' pre-post test scores were analyzed using t- test. The results indicated that there were statistically significant differences at $(0.05)$ level between the mean scores of the experimental and the control groups on the post critical thinking test as a whole and in its sub-skills (making inferences, recognition of assumptions, deductions, interpretations, and evaluating arguments )in favour of the experimental group. There were also statistically significant differences at (0.05) level between the mean scores of the experimental group on the pre-post administration of the critical thinking test as a whole and in its sub-skills in favour of the post administration. In addition, most of the students suggested that PBL encouraged them to share their opinions with others, analyze situations in different ways and think of more possibilities for solving problems. However, a few students felt stressed and overloaded during the PBL process. In conclusion, PBL promoted secondary stage students' critical thinking skills.
\end{abstract}

Key words: Problem-based learning, critical thinking, secondary stage students.

\title{
Introduction
}

In a rapidly changing world, every person is challenged to fulfill the global demand especially in developing skills. The impact of the rapid 
change in society to education is that education must prepare generation to have a certain skills needed by the society. The skills are called 21st century skills. The Partnership for 21st Century Skills has developed 21st century skills that consist of life and career skills, learning and innovation skills, and information media and technology skills.

Thinking is a necessary part of our social and intellectual lives. It is argues that the quality of our lives and of our learning depends on the quality of our thinking. Thinking is part and parcel of being intrinsic to human development and that we gain pleasure from being exposed to intellectual stimulus and challenge.

Acquiring thinking skills has been increasingly emphasized in education, especially with forces in globalization demanding its workers to be adaptable over and above being productive. Studies have recommended that students can no longer be passive recipients of given information and called for changes in pedagogical and learning environments that are geared towards developing thinking skills and utilizing creativity.

Teaching and learning process does not only increase student's knowledge but also develop student's creativity, critical thinking skill, characters which are included the character to have responsibility, social skills, tolerance, productivity, and adaptive skills (Ledward \& Hirata, 2011). 21st century skills also emphasize on the ability to think critically, solve problem, communicate, and collaborate each others that are included in higher order thinking skills (Paige, 2009 ).

Critical thinking is a mode of thinking about any subject, content, or problem. It is an ability with which students can improve their thinking quality by skilfully managing their thinking structures and intellectual criteria around them. (Paul \& Elder, 2005, updated 2014). Scriven and Paul (2004) defined critical thinking as an intellectually disciplined process in which students actively and skilfully conceptualize, apply, synthesize, and evaluate information generated by observation, experience, reflection, reasoning, and communication. Critical thinking does not expect students to answer the questions put in the class, but instead develops students' sound judgment for problem-solving, decisionmaking, and higher-order thinking. (Case, 2005).

Critical thinking is widely considered an important skill for psychology majors, as reflected in the recent APA Guidelines for the Undergraduate Psychology Major (American Psychological Association 
(APA), 2013). According to APA's Delphi Report (1990), critical thinking has six core elements: interpretation, analysis, evaluation, inference, explanation, and self-regulation. That is, students should know how to comprehend and express meaning or significance. They should know how to identify implicit and explicit relationship and to give logical assessment. Besides, after interpretation, analysis, and evaluation, they should know how to monitor their cognitive process, draw reasonable and logical conclusions, and illustrate the results. Based on APA's definition (1990), ideal critical thinkers should be inquisitive, well-informed, logical, and open-minded. Besides, they should be honest in facing their biases and be careful in making judgments.

To sum up, persons with a disposition to think critically should be persons who are inquisitive, truth-seeking, open-minded, analytic, cognitively mature, systematic, and self-confident (Ferrett, 1997). They always know how to ask appropriate questions, address arguments, and seek evidence to support their thoughts and beliefs. Moreover, they know how to reject information that is incorrect, illogical, or irrelevant.

Critical thinking is recognized as an important competence for students to acquire in academic language (Connolly, 2000), so many studies emphasized teaching it in EFL/ESL Classrooms. Examples of these studies are the following:

Julio Cesar (2010)' study investigated the impact of structured reading lessons on the development of critical thinking skills in college students learning English as a foreign language. This study took place during the first level of English in their academic program. Two groups of students were included in the study. One group received traditional reading instruction while the other group had structured reading lessons that intended to create opportunities to operate in higher order thinking levels. Results showed that students who had structured reading lessons did not improve in a significant way compared to the results of the control group in the post-test.

Hashemi \& Ghanizadeh (2012) conducted a study to investigate the impact of critical discourse analysis (CDA) on TEFL students' critical thinking (CT) ability in Reading Journalistic Texts classes. In so doing, the study utilized an experimental design with 24 participants in the control group and 29 participants in the experimental group. The participants in the experimental group were instructed to critically analyze teacher-distributed articles and devise follow-up presentations based on CDA. The results of the post-test indicated that CDA has a 
positive and significant influence on learners' critical thinking ability. CDA was also found to have the highest impact on two components of $\mathrm{CT}$, interpretation and recognizing unstated assumption.

The researcher concluded from the findings of the foregoing studies that critical thinking skills could be taught as a part of EFL instruction and can be reinforced via different techniques and activities implemented in the classroom setting. Furthermore, the abovementioned studies conclusively demonstrate the influential role EFL teachers can play in scaffolding activities and procedures which nurture and foster EFL learners' CT abilities.

Teaching critical thinking is as important as an individual being educated (Norris 1985as cited in Julio César, 2010).Evidence suggests that the complex cognitive abilities can systematically be taught (Jianzeng et al, 1997). Thus, in the recent development of pedagogical approach, one new method that has been claimed promoting students' critical thinking ability is using problem based learning (PBL). This method is generally agreed to have important implications for transfer of knowledge and application of problem solving skills to novel situations (Garcia \&Pintrich1992). This assertion has been supported by several previous research reports (Deal \&Pittman2009).

Problem Based Learning (PBL) is a motivating, challenging, and enjoyable learning approach (Norman et al, 2006) that has resulted from the process of working towards understanding or resolving a problem (Barrows, 2000). The origin of PBL can be traced to the progressive movement, especially to John Dewey's (1944) belief that teachers should teach by appealing to the students' natural instincts to investigate and create.

PBL was first introduced in the McMaster University in Canada in 1965. Soon after that, in 1974, the McMaster medical school PBL model was established. This model inspired other universities to implement a similar design into their curriculum. Since then, PBL has been popularized and used in several higher educational institutions across the world, such as in Australia, Denmark, and China (Kolmos et al, 2008).

Problem-based learning (PBL) is one of the student centered approaches that focuses on helping students develop self-directed learning skills. It derives from the theory that learning is a process in which the learner actively constructs new knowledge on the basis of current knowledge. PBL provides students with the opportunity to gain theory and content knowledge and comprehension. PBL helps students 
develop advanced cognitive abilities such as creative thinking, problem solving and communication skills (Awang \& Ramly, 2008).

However, Barrett (2010) has explained problem based learning as a situation in which learners' struggle for a solution within the framework of certain problems that have been carried out independently or as group discussions and controlled by a teacher. Problem based learning, as well as analyzing theory, model and application steps, has been especially focused upon application step. The reason for this is that there are many processes applied in universities such as Linko Èping Maastricht, Roskilde and Aalborg, in the formation of related learning approaches Kolmos, et all, 2008). So it can be said that a problem based learning approach is especially related to the field of application and makes students attain learning goals within the framework of several problems.

Based on Hmelo-Siver (2009), the goals of PBL include helping students to develop:

- Flexible knowledge.

- Effective problem-solving skills.

- Self-directed learning (SDL) skills.

- Effective collaborative skills and intrinsic motivation.

- Communication, reasoning and critical thinking skills.

\section{The Problem-Based Learning (PBL) Process:}

PBL operates in several major steps, as in the "Seven-jump" model (Maastricht PBL model). The steps can be summarized into three major stages namely; initial stage, PBL stage, and final stage (Masek and Yamin, 2010). In the first stage, the group is then presented with a PBL problem and they begin to analyse and understand the problem, and this is mostly done by defining "what they know", "what they do not know" and further "what they need to know". In this case, the teacher acts as facilitator to guide students' learning through the PBL process cycle (Hmelo-Silver, 2009).

The PBL stage begins with students performing an independent self-study (Schmidt \& Severiens, 2009). Students are expected to master the knowledge that relevant to the problem to be solved. Meanwhile, the facilitator monitors the group's progress through direct observation and formative assessment (O'Grady and Alwis, 2002). The facilitator then 
provides feedback immediately after formative assessment and always encourages students to keep up with self-assessment (Wood, 2003).

In the final stage, students prepares for a project presentation and assessment during the last meeting session. Students partially present their proposal of solution. The facilitator evaluates students' work based on either group or individual presentation (Kolmos and Holgaard, 2010).

\section{The Relationship between Problem-Based Learning and Critical Thinking}

Critical thinking is in the family of higher order thinking skills, along with creative thinking, problem solving, and decision making (Facione, 1990). Critical and creative thinking are connected to each other, in producing an effective thinking and problem solving (Treffinger et al., 2006). Evidence suggests that the complex cognitive skills can be systematically taught (Jianzeng et al., 1997). For that reason, teaching higher order cognitive abilities such as critical thinking has always been the ultimate goal of education (Spendlove, 2008).

PBL is often theorized to promote students' higher order thinking skills, especially reasoning skills (Savery, 2006). PBL is anchored by Students Centered Learning approach that follows constructivist learning theory principles (Hmelo-Silver, 2004). In this context, knowledge acquisition becomes one of the prerequisites in developing students' critical thinking ability (Hmelo-Silver, 2004; Winterton et al., 2006). According to Winterton et al. (2006), knowledge and working memory play major roles in the acquisition of complex cognitive skills. This is particularly true because knowledge is operational and working within a social and attitudinal environment.

Critical thinking is an ability to justify and reflect on what an individual believes. This in light with Ennis et al. (2005), points that critical thinking as a reasonable and reflective thinking that focuses on deciding what to believe or do. It is an analytical process of arriving at judgments that is directed by a specific end purpose to arrive at a logical, rational, and reasonable problem solution (Bailin et al., 1999; Facione, 2006). Some authors explain that critical thinking is the process of an individual taught to reason in improving the solution (Paul and Elder, 2003). Thus, the analytical process of reasoning must arrive at logical, rational, and reasonable judgments, within a given framework, and must agree with specific principles of thinking (Ennis, 1984), as proposed by Facione (2006): 
(i) Analysis = identifying and examining ideas and arguments.

(ii) Inference $=$ drawing conclusions.

(iii) Interpretation = clarifying meaning through categorization and translation.

(iv) Self-regulation $=$ self-assessment and reflection.

(v) Explanation $=$ justifying results, arguments or procedures.

(vi) Evaluation $=$ assessing arguments.

In addition, critical thinking must match to the context (Norris, 1985 cited in Masek \& Yamin , 2011) within a given framework (Bailin et al., 1999). In some other views, critical thinking matches with the value of an individual's judgment (Norris, 1985). This value of judgment may direct the students' response in regards to a certain specific context. However, when critical thinking is valued by the reasoning ability, then measuring critical thinking must include the general structure of reasoning ability, regardless of the context (Ennis, 1984 in Facione (2006) .Moreover, according to Ennis (1984), it is important to examine the structure of reasoning, since the structure represents the general meaning of reasoning ability, based on what an individual's believes.

Based on the above conceptual definition, critical thinking ability is possibly nurtured by PBL, through the process of problem solving, particularly within group brainstorming sessions (Wee, 2004). During these sessions, students critically consider one best possible solution for the problem at hand. The process is mediated by a facilitator, who is responsible for probing their meta-cognitive thinking, in making any decision (Wee, 2004). It is believed that probing questions may engage students in a systematic cognitive process that promotes the development of the students' reasoning ability.

In addition, other processes, such as discussion, debating, sharing, and teaching one another, creates a platform for students to experience an environment that is conducive for critical thinking to grow (Schmidt, 1993; Wee, 2004). Similarly, students develop their critical thinking, especially reasoning skills through the process of interaction, reflection, and feedback in the problem solving or in the formative assessment process (Schmidt, 1993).

Within this capacity, a strong basis exists that supports PBL's contribution to students' higher order thinking skills, especially critical thinking ability. The concept of "learning by doing" in the PBL approach is actually supported by Experiential Learning Theory, in which students learn thinking strategies by solving a problem (Hmelo-Silver, 2004). The 
facilitator then stimulates students' critical thinking in looking for a best solution, which is also in light with the concept of "scaffolding" from the Constructivist Learning Theory (Hmelo-Silver, 2004; Wee, 2004).

Accordance with the foregoing, the current study comes to the conclusion that there is a positive relationship between the critical thinking and problem-based learning. Through PBL process, students learn actively and that prior knowledge may be applied to new problemsolving situations. This will, in turn, significantly raise students' ability to analyze and criticize, and enhance their performance in terms of English understanding and content knowledge.

\section{Context of the problem}

To educate students for democracy, we must educate them to deal with a future we do not (and cannot) know. Democratic life is progressing and a democratic education must therefore be an education in thinking through complex problems, developing the mind toward specific aims and goals, and learning to be reflective about the paths we choose. (Elmborg ,2006, p. 5 on Dewey's educational philosophy ).

In curriculum, to achieve critical thinking skills, students must develop cognitive skills such as analyzing, making connections, making inferences and evaluation, critical thinking dispositions and habits such as disputing, searching for reasons and evidences and open-mindedness (Paul\& Elder 2014). Despite this, teaching in most Arab countries, including Egypt continues to be far too didactic and teacher-directed rather than student-centered, and are adverse to environments that foster critical thinking, creativity, and problem-solving capacities. Communication in classrooms is one-sided; teachers talk at students and see textbooks as the only source of indisputable knowledge. As noted in International Tests, notably the Trends in International Mathematics and Science Study (TIMSS), student learning relies on memorization of definitions, facts, and concepts rather than the ability to think critically (Faour, 2011).

Despite secondary education stage in Egypt aims at preparing students for practical life as well as developing their everyday life skills including their critical thinking skills(Ministry of Education,2014), the current study suggests that there appears to be a lack in exposure to critical thinking based activities in many Egyptian secondary classrooms. 
In Egypt where the education system is still very much examoriented and result-based, lecturers/teachers may hesitate to employ alternative methods to promote critical thinking, choosing instead to focus more on finishing the syllabus and teaching students how to score well in exams.

\section{The pilot Study}

The researcher administered a critical thinking test to a randomly selected $301^{\text {st }}$ grade secondary students from Abd Al Aziz Al Saud experimental school to find out how well students are able to think analytically and logically and to investigate the students'scores in critical thinking skills .The result of piloting the test revealed that more than $70 \%$ of students had low scores concerning their critical thinking skills such as making inference, recognition of assumptions, deduction, interpretation, and evaluation of ideas .Students expressed their unfamiliarity with critical thinking skills.

In the light of the foregoing justifications, the teaching process must reconsider its methods and modalities, and develop effective methods which enable students to promote critical thinking skills and be active and creative users of English. Thus, this study aims to design suggested educational program based on problem-based learning and measure its impact on development critical thinking skills among $1^{\text {st }}$ grade secondary stdents.

\section{Statement of the problem}

Most secondary stage EFL students -at Abd Al Aziz Al Saud experimental school -lack the necessary critical thinking skills that would enable them to make a positive decision that would achieve the goals they desire, increase the output of learning, and promote creativity and innovation of learners. Therefore, the present study aims mainly to answer this question: What is the effectiveness of problem-based learning program in developing critical thinking skills among the secondary stage EFL students?

\section{Research questions:}

These questions are derived from this main question:

1. What are the critical thinking skills necessary for the $1^{\text {st }}$ first grade secondary students? 
$r$. What is the effect of using problem-based learning program on developing these skills?

\section{Purpose of the study}

\section{This study aimed at:}

1. Determined the critical thinking skills that secondary schools students are in need of to develop their critical thinking ability in the $21^{\text {st }}$ century.

2. Assessing the effect of using problem-based learning program on developing critical thinking skills?

\section{Significant of the study}

This study may be instructionally effective in the following areas:

- Providing English teachers with fresh ideas for teaching and learning that might be used to improve critical thinking of secondary stage students, in times of rapid movement in technology and scientific knowledge.

- Shifting the minds of students from rote learning and memorising to a notion where they see value and engaging higher level cognitive activity like critical thinking that comes through problem-based learning (PBL).

- Developing secondary students' critical thinking skills and enhancing motivation towards learning English through problembased learning.

- Increasing the learning skills of students as well as their hands-on skills that come through PBL to prepare them for a challenging working environment.

\section{Method}

\section{Participants}

The Participants of this study were 60 of $1^{\text {st }}$ grade secondary students at Abd El-Aziz Al Soud Experimental Language School in Cairo. The participants were randomly selected and then divided into two groups; an experimental group and a control one. Each group comprised 30 students: 30 females and 30 males. Their age was $15-16$ years (M $=15.50, \mathrm{SD}=0.15)$.The descriptive data for the students participated in the study is shown in Table (1). 
Table (1): The descriptive data for the participants.

\begin{tabular}{|c|c|c|c|c|}
\hline \multirow[t]{2}{*}{ Participants } & & \multicolumn{2}{|c|}{ Gender } & \multirow[t]{2}{*}{ Total } \\
\hline & & Female & Male & \\
\hline experimental & $1 / 11^{\text {st }}$ grad secondary & 15 & 15 & 30 \\
\hline Control & $1 / 21^{\text {st }}$ grad secondary & 15 & 15 & 30 \\
\hline Total & & 30 & 30 & 60 \\
\hline
\end{tabular}

\section{Instruments}

The present study comprised from main instruments:

\section{The Critical Thinking Skills Checklist (CTSC)}

\section{Description of the critical thinking skills checklist}

The initial version of the critical thinking skills checklist included fifteen skills .To validate the checklist, it was submitted to a panel of specialized juries in the field of TEFL to judge the appropriateness of the skills to $1^{\text {st }}$ secondary students and the degree of importance of each skill. The respondents were asked to rate each item of critical thinking skills through a 5-point Likert Scale; "strongly agree (5)", "Agree (4)", "neutral (3)", "strongly Disagree (2)", "Disagree (1)".

In light of the jury members' opinions and comments, some modifications were made to finalize the checklist. The final version was composed of five main critical thinking skills namely; drawing inferences from fact, recognition of assumptions implied by a statement, deductive reasoning, logical interpretation and evaluation of arguments.

\section{Watson-Glaser Critical Thinking Appraisal - Short Form (WGCTA- FS)}

The test aimed to measure $1^{\text {st }}$ grade secondary students' critical thinking skills. The test was adapted from the authors (Watson and Glaser, 2006) by written permission. The critical thinking skills under investigation were inference, recognition of assumption, deductive, interpretation and evaluation of arguments. 


\section{Satisfaction questionnaire}

Students' satisfaction questionnaire was adapted to understand $1^{\text {st }}$ grade secondary students' opinions of learning via a PBL approach, and to find out which learning outcomes they felt they had achieved .The questionnaire was administered after the PBL experiment on the experimental group.

\section{The program}

\section{Aim of the program}

The overall aim of the program is to develop the critical thinking skills of $1^{\text {st }}$ grade secondary students .Specifically, the program aims to develop four critical thinking skills ; namely, making inference, recognizing of assumption ,making deductions, making interpretations , and evaluating arguments using Problem-Based Learning (PBL) as an innovative learning approach.

\section{Content of the Program}

The program is composed of one English module contains different reallife problems that provide presentations of social problems. With PBL, the instructor presents the students with a problem, not lectures or assignments or exercises. Since the students are not handed "content", their learning becomes active in the sense that they discover and work with the content that they determine to be necessary to solve the problem. Some of The problems are not from the students textbooks, but are suitable for $1^{\text {st }}$ grade secondary students and more related to their daily lives; problems that simulate the kind of ones they are likely to face as future professionals in today's challenging world.Each problem focuses on two or more critical thinking skills. The suggested time for each problem is nine hours .The design of each problem depends upon a suggested instructional approach which is problem based learning. The program was modified according to the opinion and suggestions of a group of specialists; including professors of teaching methodology, supervisors of English Language in addition to highly qualified and experienced English teachers. 


\section{Results}

Results are reported in terms of the study hypotheses

\section{Verifying the first hypothesis}

The first hypothesis states "There is a statistically significant difference between the mean scores of the experimental group students on the pre and post administration of the critical thinking test as a whole and in its sub-skills favoring their post test scores."

In order to verify this hypothesis, the researcher compared the mean scores of the experimental group students on the pre and post administration of the critical thinking test as a whole and in its sub-skills .Also the researcher has used t.test to find out the significant differences before and after conduction the program. The results of the $t$-test proved to be statistically significant. Table (2) shows the results.

Table (2): $t$-test results of the pre and post administration of the experimental group students' critical thinking test as a whole and its sub-skills

\begin{tabular}{|c|c|c|c|c|c|c|c|}
\hline $\begin{array}{c}\text { critical } \\
\text { thinking } \\
\text { skills }\end{array}$ & $\begin{array}{c}\text { The experimental } \\
\text { group }\end{array}$ & $\mathbf{N}$ & mean & $\begin{array}{l}\text { Standard } \\
\text { deviation }\end{array}$ & $\begin{array}{l}\text { Critical } \\
\text { value }\end{array}$ & Significance & Effect size \\
\hline \multirow{2}{*}{$\begin{array}{l}\text { making } \\
\text { inferences }\end{array}$} & The pre administration & 30 & 3.23 & 0.43 & \multirow{2}{*}{$8.44 * *$} & \multirow{2}{*}{$\begin{array}{l}\text { Significance } \\
\text { at } 0.05\end{array}$} & 0.71 \\
\hline & The post administration & 30 & 4.30 & 0.95 & & & Large \\
\hline \multirow{2}{*}{$\begin{array}{l}\text { recognition of } \\
\text { assumptions }\end{array}$} & The pre administration & 30 & 3.90 & 0.60 & \multirow{2}{*}{$8.57 * *$} & \multirow{2}{*}{$\begin{array}{l}\text { Significance } \\
\text { at } 0.05\end{array}$} & 0.72 \\
\hline & The post administration & 30 & 5.30 & 1.11 & & & Large \\
\hline \multirow{2}{*}{$\begin{array}{c}\text { making } \\
\text { deductions }\end{array}$} & The pre administration & 30 & 4.30 & 0.46 & \multirow{2}{*}{$7.95 * *$} & \multirow{2}{*}{$\begin{array}{c}\text { Significance } \\
\text { at } 0.05\end{array}$} & 0.69 \\
\hline & The post administration & 30 & 5.90 & 1.37 & & & Large \\
\hline \multirow{2}{*}{$\begin{array}{l}\text { making } \\
\text { interpretations }\end{array}$} & The pre administration & 30 & 3.63 & 0.55 & $7.94 * *$ & $\begin{array}{c}\text { Significance } \\
\text { at } 0.05\end{array}$ & 0.68 \\
\hline & The post administration & 30 & 4.73 & 0.94 & & & Large \\
\hline \multirow{2}{*}{$\begin{array}{l}\text { evaluating } \\
\text { arguments }\end{array}$} & The pre administration & 30 & 4.13 & 0.43 & \multirow{2}{*}{$7.39 * *$} & \multirow{2}{*}{$\begin{array}{l}\text { Significance } \\
\text { at } 0.05\end{array}$} & 0.65 \\
\hline & The post administration & 30 & 5.86 & 1.52 & & & Large \\
\hline \multirow[t]{2}{*}{$\begin{array}{l}\text { skills as a } \\
\text { whole }\end{array}$} & The pre administration & 30 & 19.20 & 1.91 & \multirow{2}{*}{$9.46 * *$} & \multirow{2}{*}{$\begin{array}{c}\text { Significance } \\
\text { at } 0.05\end{array}$} & 0.80 \\
\hline & The post administration & 30 & 26.16 & 5.58 & & & Large \\
\hline
\end{tabular}


As shown in table ( 1 ), there are statistically significant differences between the mean scores of the experimental group students on the pre and post administration of the critical thinking test in each separate critical thinking skill and in critical thinking as a whole in favour of post administration because the calculated t values are (8.44) for making inferences,( 8.57) for recognition of assumptions, (7.95) for making deductions , (7.94) for making interpretations,( 7.39) for evaluating arguments , (9.46) for critical thinking skill as a whole. Also the t. value points out that there is statistically significance which reached (9.46) and it is higher than T. table (1.69) at the significant level of (0.05).Also, the mean scores of the post test which equals (4.30) for making inferences, (5.30) for recognition of assumptions , (5.90) for making deductions , 4.73) for making interpretations , (5.86) for evaluating arguments, and (26.16) for critical thinking as a whole. So, the first hypothesis was confirmed. Accordingly, the problem based learning program has an effect on the experimental group students' performance in each separate critical thinking skill and in critical thinking as a whole.

\section{Verifying the second hypothesis}

The second hypothesis states that "There is statistically significant difference between the mean scores of the experimental group and the control group on the post administration of the critical thinking test as a whole and in its sub-skills favoring the experimental group ".

In order to verify this hypothesis, the researcher compared the mean scores of the experimental and control group students on the post administration of the critical thinking test as a whole and in its sub-skills .Also the researcher has used t. test to find out the significant differences after conduction the program. The results of the $\mathrm{t}$-test proved to be statistically significant. Table (2) shows the results.

Table (3): t-test results of the post administration of the experimental group students' critical thinking test as a whole and its sub-skills 


\begin{tabular}{|c|c|c|c|c|c|c|c|}
\hline $\begin{array}{c}\text { critical } \\
\text { thinking skills }\end{array}$ & $\begin{array}{c}\text { The post } \\
\text { administration }\end{array}$ & $\mathbf{N}$ & mean & $\begin{array}{l}\text { Standard } \\
\text { deviation }\end{array}$ & $\begin{array}{c}\text { Critical } \\
\text { value }\end{array}$ & $\begin{array}{c}\text { Level of } \\
\text { Significance }\end{array}$ & $\begin{array}{l}\text { Effect } \\
\text { size }\end{array}$ \\
\hline \multirow{2}{*}{$\begin{array}{l}\text { making } \\
\text { inferences }\end{array}$} & The control group & 30 & 3.90 & 0.48 & \multirow[b]{2}{*}{$2.05^{*}$} & \multirow{2}{*}{$\begin{array}{l}\text { Significant } \\
\text { at } 0.05\end{array}$} & 0.07 \\
\hline & $\begin{array}{l}\text { The experimental } \\
\text { group }\end{array}$ & 30 & 4.30 & 0.95 & & & Average \\
\hline \multirow{2}{*}{$\begin{array}{l}\text { recognition of } \\
\text { assumptions }\end{array}$} & The control group & 30 & 4.40 & 0.77 & \multirow[b]{2}{*}{$3.62 * *$} & \multirow{2}{*}{$\begin{array}{l}\text { Significance } \\
\text { at } 0.05\end{array}$} & 0.19 \\
\hline & $\begin{array}{l}\text { The experimental } \\
\text { group }\end{array}$ & 30 & 5.30 & 1.12 & & & Large \\
\hline \multirow{2}{*}{$\begin{array}{c}\text { making } \\
\text { deductions }\end{array}$} & The control group & 30 & 4.80 & 0.96 & \multirow[b]{2}{*}{$3.59 * *$} & \multirow{2}{*}{$\begin{array}{l}\text { Significance } \\
\text { at } 0.05\end{array}$} & 0.18 \\
\hline & $\begin{array}{l}\text { The experimental } \\
\text { group }\end{array}$ & 30 & 5.90 & 1.37 & & & Large \\
\hline \multirow{2}{*}{$\begin{array}{c}\text { making } \\
\text { interpretations }\end{array}$} & The control group & 30 & 4.00 & 0.58 & \multirow[b]{2}{*}{$3.61 * *$} & \multirow{2}{*}{$\begin{array}{l}\text { Significance } \\
\text { at } 0.05\end{array}$} & 0.18 \\
\hline & $\begin{array}{l}\text { The experimental } \\
\text { group }\end{array}$ & 30 & 4.73 & 0.94 & & & Large \\
\hline \multirow{2}{*}{$\begin{array}{l}\text { evaluating } \\
\text { arguments }\end{array}$} & The control group & 30 & 5.03 & 1.03 & \multirow[b]{2}{*}{$2.47 *$} & \multirow{2}{*}{$\begin{array}{l}\text { Significance } \\
\text { at } 0.05\end{array}$} & 0.10 \\
\hline & $\begin{array}{l}\text { The experimental } \\
\text { group }\end{array}$ & 30 & 5.86 & 1.52 & & & Average \\
\hline \multirow[t]{2}{*}{$\begin{array}{l}\text { skills as a } \\
\text { whole }\end{array}$} & The control group & 30 & 22.03 & 3.40 & \multirow{2}{*}{$3.45^{* *}$} & \multirow{2}{*}{$\begin{array}{l}\text { Significance } \\
\text { at } 0.05\end{array}$} & 0.17 \\
\hline & $\begin{array}{l}\text { The experimental } \\
\text { group }\end{array}$ & 30 & 26.16 & 5.58 & & & Large \\
\hline
\end{tabular}

As shown in table ( 1 ), there are statistically significant differences between the mean scores of the experimental and control group students on the post administration of the critical thinking test in each separate critical thinking skill and in critical thinking as a whole in favour of the experimental group because the calculated $t$ values are (2.05) for making inferences, ( 3.62) for recognition of assumptions, (3.59) for making deductions, (3.61) for making interpretations,( 2.47) for evaluating arguments , (3.45) for critical thinking skill as a whole. Also the t. value points out that there is statistically significance which reached (3.45) and it is higher than T. table (1.69) at the significant level of (0.05).Also, the mean scores of the post test which equals (4.30) for making inferences, (5.30) for recognition of assumptions, (5.90) for making deductions , 4.73) for making interpretations, , 5.86) for evaluating arguments, and (26.16) for critical thinking as a whole is bigger than the mean scores of 
the control group which equals (3.90) for making inferences , (4.40) for recognition of assumptions, (4.80) for making deductions, (4.00) for making interpretations, (5.03) for evaluating arguments, and (22.03) for critical thinking as a whole. So, the second hypothesis was confirmed. Accordingly, the program has an effect on the experimental group students' performance in each separate critical thinking skill and in critical thinking as a whole.

From what has been mentioned, it is clear that the hypotheses which the study has set to determine the effectiveness of problem base learning program on developing the $1^{\text {st }}$ grade secondary students' critical thinking was verified.

\section{Discussion}

The purpose of this study is to investigate the effect of using problem base learning program on developing the $1^{\text {st }}$ grade secondary students' critical thinking. The t.test was used to compare the mean scores of the the experimental group students and those of the control group students in the critical thinking post - test. The results showed that there were statistically significant differences between the mean scores of the experimental group and the control group in the critical thinking post -test in favour of the scores of the experimental group student's .The researcher attributed this improvement to using problem based learning training.

The results of the current study proved that problem based learning program had a positive impact on the critical thinking of EFL $1^{\text {st }}$ grade secondary students. These findings are agreement with a study conducted by Yuan et al (2008) who concluded that students, who experienced PBL showed greater improvement in critical thinking skills, motivated them to learn, allowed them the opportunity to share opinions with others.

Similar finding was recognized in a study conducted by EL-Shaer \& Gaber ( 2014) who proved that PBL improved students' critical thinking dispositions, knowledge acquisition and retention among PBL students compared to lecture students. Although, the result of Sulaiman (2011) which indicated that there was no statistical difference for critical thinking between the control and the experimental groups, but some further analysis indicated that PBL students had better skills in making inference and evaluation argument criteria than the traditional method students. 
These findings are consistent with research findings reported by Azmi et al .(2016) who proved that that problem-based learning is suitable and beneficial in teaching and enhancing critical thinking skills.Wahyu \& Marlina ( 2017) supported the present study and showed that the mean gain of students' critical thinking and problem solving ability taught by problem based learning was better than conventional learning, this result showed that there was an effect of problem-based learning model on students' critical thinking and problem-solving ability.

In contrasting with the result of this study, the findings of Anderson study (2007) reported that beyond higher education context, the PBL instruction did not change the students' critical thinking ability in school level . The pre-test and post-test on 110 secondary students in controlled and experimental group did not significantly different in their critical thinking ability.

Also these findings are inconsistent with research findings reported by Masek (2012) who conducted a study to examine the effects of Problem Based Learning (PBL) on students' knowledge acquisitions, critical thinking ability, and intrinsic motivation for the polytechnic's electrical engineering course. The results indicated that PBL enhances students' knowledge acquisitions and intrinsic motivation, but does not improve students' critical thinking ability as compared to conventional approach.

\section{Conclusion}

This study investigated the effect of problem-based learning on developing $1^{\text {st }}$ grade secondary EFL students' critical thinking ability. After conducting the program, the critical thinking for PBL students increased as expected. In conclusion using problem-based learning in EFL classes has many advantages such as:

- The use of the PBL highly contributed to enabling students generate ideas, exchange opinions and clarify new thoughts about the raised topics, that positively affected their performance on the post- critical thinking test.

- Through PBL, students were engaged in a holistic form of the teaching and learning process (e.g., content learning; skill of learning; also learning with minds-on and hands-on), which is different to their traditional experiences. Although at the beginning 
students were a confused, the outcomes from this study suggest that PBL can be useful for secondary students.

- PBL encourages students to learn new materials and concepts when solving problems.

- It develops students' high level thinking/critical thinking and problem -solving skills.

- It allows students to merge their old knowledge with new knowledge and to develop their judging skills.

- Students acquire the skills of time management, focusing, data collection, report preparation and evaluation.

- The students learn to actively participate in the PBL work. Since a PBL session always closes with self- and peer- assessment, the students feel confidence that their opinion and work is important for the group so they become more motivated and their learning efficiency grow.

\section{References}

American Philosophical Association. (1990). Critical thinking: A statement of expert consensus for purposes of educational assessment and instruction. The Delphi report: Research findings and recommendations prepared for the committee on pre-college philosophy. Milbrae, CA: California Academic Press. (ERIC Document Reproduction Service No. ED315423).

American Psychological Association. (2013). APA guidelines for the undergraduate psychology major: Version 2.0. Washington, DC: Author. Retrieved from http://www.apa.org/ed/precollege/about/psymajor-guidelines.pdf

Anderson, J. (2007).Effect of Problem Based Learning on Knowledge Acquisition, Knowledge Retention and Critical Thinking Ability of Agricultural Students in Urban Schools, (2007), University of Missouri: Ph.D. Thesis.

Awang,H.,\& Ramly,I.(2008).Creative Thinking Skill Approach through Problem-Based Learning: Pedagogy and Practice in the Engineering Classroom .International Journal of Human and Social Sciences, 3(1).

Azmi,M.,Abidin ,S.,\& Abd Rahman,M .( 2016).The Impacts of 'Problem-Based Learning' Approach in Enhancing Critical Thinking Skills to Teaching Literature. International Journal of Applied Linguistics \& English Literature, 5 ( 6) .

Bailin, S., Case, R., Coombs, J., \& Daniels, L.B. (1999).Conceptualizing critical thinking. Journal of Curriculum Studies, 31(3), pp.285-302.

Barrett T (2010). The problem-based learning process as finding and being in flow. Innovations in Education and Teaching International, 47(2), pp 165-174. 
Barrows, H. (2000). Problem Based Learning applied to medical education . Spring field, IL: SIU School of Medicine.

Case, R. (2005). Moving critical thinking to the main stage. Education Canada, 45(2), 45-49.

Connolly, M. (2000). What we think we know about critical thinking. Centre for Effective Learning Environments (CELE) Journal, 8, .Retrieved May, 2015 from http://www.asiau.ac.jp/english/cele/articles/Connolly_Critical-Thinking.htm.

Deal, K. H., \& Pittman, J. (2009) .Examining predictors of social work student's critical thinking skills. Advance in Social, vol. 10, no. 1, pp. 87-102.

EL-Shaer.A .,\& Gaber,H.( 2014).Impact of Problem-Based Learning on Students Critical Thinking Dispositions, Knowledge Acquisition and Retention. Journal of Education and Practice ,5(14), 2014.

Elmborg, J. (2006). The other Dewey. In G. Gibson (Ed.), Student engagement and information literacy (pp. 1-15). U.S.A.: Association of College and Research Libraries.

Ennis, R., Millman ,J.,\& Tomko, T. (2005).The Cornell Critical Thinking Tests, Level X and Z,(5th ed. revised), Pacific Grove, California: Midwest Publications.

Facione,P . (1990).Critical thinking: A statement of expert consensus for purposes of educational assessment and instruction, The Delphi Report, 1-19, California: California Academic Press.

Facione,P . (2006).Critical thinking: what it is and why it counts, Insight Assessment, California, 1-22, United States: California Academic Press.

Faour ,M. (2011)Will the Arab Spring lead to a revolution in education? Forien policy Available at : http://foreignpolicy.com/2011/11/01/will-the-arab-spring-lead-to-arevolution-in-education/

Ferrett, S. (1997). Peak performance. Cited in GED 20902: Online Professional Developmen ,from http://www.ket.org/ged2002/critical/cr3.htm.

Garcia, T., \& Pintrich, R. (1992) .Critical thinking and its relationship to motivation, learning strategies, and classroom experience. Report of the Annual Meeting of the American Psychological Association, American Psychological Association, Washington, DC.

Hashemi, M.R., \& Ghanizadeh,A. (2012). Critical discourse analysis and critical thinking: An experimental study in an EFL context. System, 40, (1) pp. 37-47.

Hmelo-Silver, C. (2004) .Problem-based learning: what and how do students learn? Educational Psychology Review, 16 (3), pp. 235-266. 
Hmelo-Silver, C. E. (2009). What do We Know about Problem Based learning? Current Status and Future Prospects, 2nd International Problem based Learning Symposium, Republic Polytechnic, Singapore.

Jianzeng, L. Yanbao, L.,Yi, C.,\& Wenxian, W.( 1997). Evaluating creative thinking of students and creativity development at southeast University, China. FIE '97 Proceedings of the Frontiers in Education Conference. American Society of Engineering Education, 7(1) pp. 576-579.

Julio César Gómez B.(2010 ).The Impact of Structured Reading Lessons on the Development of Critical Thinking Skills. Electronic Journal of Foreign Language Teaching, 7 ( 1), pp. 32-48.

Kolmos, A. \& Holgaard, J.E. (2010). Responses to Problem Based and Project Organised Learning from Industry. International Journal of Engineering Education, 26(3), $573-$ 583.

Kolmos, A., Du, X., Dahms, M., \& Qvist, P. (2008). Staff Development for Change to Problem Based Learning. International Journal of Engineering Education, 24(4), 772-782.

Ledward, B. C., and D. Hirata. 2011. An overview of 21st century skills. Summary of 21st Century Skills for Students and Teachers, by Pacific Policy Research Center. Honolulu: Kamehameha Schools-Research \& Evaluation.

Masek,A .,\& Yamin, S. (2010). Problem based learning model: A collection from literature, Asian Social Science, 6(8), pp. 148-156.

Masek,A.,\& Yamin, S .( 2011).The effect of problem based learning on critical thinking ability: a theoretical and empirical review.International Review of Social Sciences and Humanities 2 (1), 215-221.

Masek, A. (2012). The effects of problem based learning on knowledge acquisition, critical thinking, and intrinsic motivation of electrical engineering students. Ph.D. thesis, Universiti Tun Hussein Onn Malaysia.

Ministry of Education, Arab Republic of Egypt,. (2014). Strategic Plan for PreUniversity Education Reform in Egypt 2014-2030. Available online at: http://planipolis.iiep.unesco.org/upload/Egypt/Egypt_Strategic_Plan_\%20PreUniversity_Education_2014-2030_eng.pdf

Norman, G. R. ,Mamede, S., \& Schmidt, H. G. (2006). Innovations in problem-based learning: what can we learn from recent studies? Advances in Health Sciences Education, 11, 403- 422.

O'Grady, G., \& Alwis, W. A. M. (2002). One day-one problem: PBL at the Republic Polytechnic. Paper presented at the 4thAsia-Pacific Conference on PBL, Hatyai, Thailand. 
Paige, J .( 2009 ).The 21st Century Skills Movement. Educational Leadership Partnership, 9 (67).

Paul, R. W., \& Elder, L. (2014). The miniature guide to critical thinking concepts and tools. Tomales, CA: Foundation for Critical Thinking Press.

Paul,R., \& Elder, L. (2003).The Miniature Guide to Critical Thinking: Concepts and Tools, (4th Ed.), California: The Foundation for Critical Thinking.

Savery, J. R. (2006).Overview of problem based learning: definition and distinctions. The Interdisciplinary Journal of Problem Based Learning, 1, (1), pp. 9-20.

Schmidt, H. G., \& Severiens, S. E. (2009). Academic and social integration and study progressin problem based learning. Higher Education, 58, pp.59-69

Schmidt, H. (1993).Foundations of problem based learning: Some explanatory notes, Med. Edu., 27, 422-432.

Scriven, N. \& Paul, R. (2004). Defining Critical Thinking. Retrieved June 2012 from: http://www.criticalthinking.org/aboutCT/definingCT.shtml.

Spendlove, D . (2008).Creativity in education: a review, Design and Tech. Edu.: An International Journal, 10(2), 9-18.

Sulaiman,F. (2011). The Effectiveness of Problem Based Learning Online on Students' Creative and Critical Thinking in Physics at Tertiary Level in Malaysia, (2011), University of Waikato:Ph.D. Thesis.

Treffinger, D., Isaksen, S.,\& Dorval ,B.( 2006). Creative problem solving: An introduction, ,Waco, TX: Prufrock Press.

Wahyu,E., Marlina,S. ( 2017).The Effect of Problem Based Learning (PBL) Model toward Student's Critical Thinking and Problem Solving Ability in Senior High School.American Journal of Educational Research, 5(6), 633-638.

Watson, G., \& Glaser, E. (2006). Watson-Glaser Critical Thinking Appraisal, Short Form manual. San Antonio, TX: Pearson.

Wee,K .(2004). Jump Start Authentic Problem Based Learning, Singapore: Prentice Hall Pearson Education South Asia Pte. Ltd.

Winterton, J., Delamare-Le Deist F., \& Stringfellow, E.( 2006). Typology of Knowledge, Skills and Competences: Clarification of the Concept and Prototype, Luxembourg: Office for Official Publication of the European Community, Luxembourg, Germany.

Wood, D. (2003). ABC of learning and teaching in medicine: Problem based learning. British Medical Journal , 326(7384), pp.328-330. 
Yuan, H .,Kunaviktikul .W., Klunklin ,A., Williams ,B.(2008). Promoting Critical Thinking Skills Through Problem-Based Learning.Nursing Health Science. 2008 10(1)pp:70-6. doi: 10.1111/j.1442-2018.2007.00373.x. 